\title{
What Europe Expects of Post-Merkel Germany
}

Europe expects Germany's likely new Chancellor, Olaf Scholz, to keep the Union together while adding more strategic vision to fight climate change, transform the European economy and navigate global politics.

The German election has yielded the expected result: Olaf Scholz and his Social Democrats (SPD) came out strongest and will try to form a government with the Greens and the socially liberal but economically conservative Free Democrats (FDP). Negotiations for that so-called "traffic light" coalition will take time and will involve some drama but, as things stand, the parties in question will come to an agreement in the end. Scholz's relative popularity, the SPD coming in first by some margin, and the historically bad result for the Christian Democrats (CDU) all make it very hard to argue that Armin Laschet, the CDU leader, has received a popular mandate to form a government. The platforms of the three "traffic light" coalition parties also leave enough room for compromise on some of the thornier issues. And the FDP and the Greens are already in bilateral talks to find common ground vis-à-vis the larger SPD.

Europe is watching in nervous anticipation. While European issues played next to no role in the election campaign, the next government will face a full list of issues to resolve at the European level, such as badly needed reforms to Europe's fiscal rules, the Fit for 55 package to put lofty climate goals into action, foreign policy challenges like the crisis in Belarus and the war in Ukraine, the EU's strategy in the Western Balkans, the migration pact with Turkey, a common position vis-à-vis China on investment, human rights and Pacific security, as well as how to tax global companies, and the reform of competition rules. The list goes on and on.

There are three types of European expectations on Germany. The first is for Germany to remain a reliable partner. Germany's most important role in Europe is forging compromise between competing interests and keeping Europe united. The EU is not a transactional project for Berlin, nor a means to enhance German power. It is the core of Germany's national interest. Germany's role as compromise builder has only been strengthened by Brexit: smaller North-Western states and Central and Eastern European governments could previously rely on Britain to take their interests into account; Berlin will now have to shoulder more of that responsibility. Angela Merkel was a gifted negotiator and tactician, briefed on every detail of a critical dossier and aimed to find solutions that everyone - herself included - could live with. Every German chancellor will have to play that role. Scholz is likely to do so well, given his political experience and sober persona, even though it will take time to acquire Merkel's political standing among European leaders.

The second expectation on Germany is for Berlin to lead on modernising the European economy and fighting climate change. The worst parts of Merkel's legacy are the missed opportunities of the 2010s to bring Europe back to full employment and use low interest rates to invest in Europe's future and the fight against climate change. In Europe, Merkel backed austerity and reforms aimed at reducing deficits, which did not generate the economic growth that their proponents promised. In Germany, she led governments that spent most of their fiscal surpluses on increasing pensions - in part undoing earlier reforms - instead of pushing with urgency for investment in digital infrastructure, innovation or preparing the country for the fight against climate change. As a result, it took the eurozone until 2016 to return to the economic output level of 2008 , and it will take Germany a decade to correct the low levels of

(C) The Author(s) 2021. Open Access: This article is distributed under the terms of the Creative Commons Attribution 4.0 International License (https://creativecommons.org/licenses/by/4.0/).

Open Access funding provided by ZBW - Leibniz Information Centre for Economics. 
public investment of the Merkel years. Germany exited nuclear energy during her time in office, while remaining one of the worst polluters per capita in the world to this day.

Towards the end of the Merkel years, political priorities changed for several reasons. Brexit, and the election of Donald Trump as US president, had shown the populist potential of economic hardship even in mature democracies. The increasingly assertive authoritarian states in Europe's neighbourhood had emphasised that an economically strong and politically united Europe was more important than ever. China's increasing use of its vast power to influence policies in Europe had convinced many that susceptibility to Chinese economic blackmail had huge political costs. Meanwhile, the assessment of the economic policies of the previous decade and the emergence of a new generation of German economists had made the debate on public spending and debt less dogmatic; negative interest rates and strongly declining public debt in Germany had lowered the perceived threat of public debt in the eyes of the public; and finally, climate change had become the single biggest concern of German voters, convincing many policymakers that all tools should be available to fight it, even if that meant crossing German red lines.

One such red line was crossed by Merkel herself, in response to the pandemic and backed by a surprisingly large segment of Germany's economic policy community. Together with her finance minister, Olaf Scholz, she put together a recovery fund for the EU that not only involved up to $€ 750$ billion of common EU debt but also sizeable transfers to economically weaker countries in the south and east of Europe. The fund focuses on reforms and investments to make the European economy fit for the 21st century, including digitalisation and the green transition.

Many European countries expect that change of German policy to continue, though not necessarily in the form of transfers like the current fund. High on the agenda is a green re-think of Europe's fiscal rules to allow for the needed public investment (and support of private investment) to happen all across Europe to reach net zero. Germany's coalition agreement will set the tone of that debate, and hence Europe's eyes are on the SPD and the Greens to put a strong emphasis on greening Germany's fiscal rules first. That is doable within a "traffic light" coalition. The FDP realises that reaching net zero with carbon prices alone creates strong political resistance, and is keen to help Germany's Mittelstand companies become innovators on climate. The new coalition may agree to a $€ 500$ billion climate transition fund that supports both public and private investment outside the fiscal rules. That in turn could become a model for a green investment clause in the fiscal rulebook of Europe.

The third expectation on Germany is to help Europe become a robust actor in foreign policy, which may entail an economic cost. That is arguably the trickiest task for the next German government. Both the FDP and the Greens have signalled that they back a tougher European approach towards autocratic regimes, including China. Scholz has voiced his support for a better-equipped Bundeswehr to underline Europe's military strength, contrary to the views of others in the party. But talk is cheap. The gas crisis unfolding in Europe provides a first opportunity, especially for the SPD. After backing the Nord Stream 2 gas pipeline from Siberia to the German Baltic coast, much to the horror of European partners, it is on Berlin to show that Germany is willing to stand up to Russia in a geo-economic conflict. But Europe should not expect too much: The new government will only carefully deviate from Merkel's course which included the yet-to-be-concluded investment agreement with China, a migration pact with Turkey and Nord Stream 2 - and will focus first on strengthening alliances and building a common strategic outlook in Europe and with the US.

Christian Odendahl, Centre for European Reform, Berlin, Germany.
A decade of crises has left Europe with an impressive to-do list. Scholz and his "traffic light" government will need a more strategic vision for Germany and Europe than the Merkel governments, but the same ability to find compromise and common European positions on thorny political issues. Merkel had a challenging decade of crisis to manage in her final terms. Scholz will not have it any easier. 